\title{
ドイツの大学における意思決定機関の 構成原理
}

はじめに

ドイッの「大学制度の一般原則」を定める連邦法である大学大綱法 (Hochschulrahmengesetz, HRG）は，その第58条第 1 項で大学が「法律の範囲内で自治権を有する」ことを定 めている。大学の「自治」は大学が自律的に管理されることを意味するが，その内容は二 面的である。

それは第一に対外的な「自治」である。これは特に大学と国家の関係において現れる。 ドイツ大学の法的地位に関する「国家の営造物であると同時に, 公法上の社団でもある二 重の性格」についての論争も，大学対国家の視点から論じられたものであった。第二の面 は大学内部管理の問題である。大学の対外的な「自治」は意思決定に対する国家の影響力 を排除するのみであり, これは大学内部の管理のモデルを示すものではない。従って後者 は前者とは別個に検討する必要がある。そこで重要な意味をもつのは，大学の意思決定過 程である。とりわけ意思決定機関の議決権をもつのは誰かといらこと, つまり意思決定機 関が如何なる原理によって構成されるのかといらことがその核心にある。

意思決定機関の構成の原則は大学大綱法に定められている。この法律は1976年に施行さ れたが，1985年11月に大幅に改正された (第三次改正)。この際に評議会の構成原理とし て, 従前の集団代表制原理 (Prinzip der Gruppenvertretung) に加えて，大学の専門上の 組織編成を考慮する専門代表制原理 (Prinzip der Fachvertretung) が導入された。これに ついてティーメ（W. Thieme）は，旧法による集団管理大学で失われていた専門上の構成 に対する配慮に，再び多くの重要性を与える試みであり，また大学成員の資格は非常に軽 視されていたが, 専門部の代表もそのまま評議会の構成員とされるならば, 大学大綱法第 3 次改正法はこの問題を解消しょうとするものであると評価した。しかし，ここで採り上 げられた原理相互の関係は明確には論じられていない。

そこで本稿では, まずドイッ大学の管理運営原理の中心をなす二つの原理の本質及び両 
原理の関係を考察し, 大学大綱法第三次改正にお沙る意思決定機関の構成原理の改変の成 果を明らかにすることによって，ドイツに和ける大学自治の一断面の解明を試みる。な 扣，本稿の対象とする大学は，旧西ドイッの総合大学 (Universität)である。

\section{1. 大学大綱法と意思決定機関の構成原理}

\section{(1) 歴史的背景}

ドイツの大学の意思決定が如何に行われるべきかといら今日の課題を論ずる場合に，そ の歴史的背景を無視することはできない。現行の管理体制は，14世紀に䑙けるドイツ大学 の成立以来発展してきたものではなく，むしろそれを否定することによって構築されたも のだからである。1810年のベルリン大学の創設を起源とする「古典的時代」は，1970年頃 までに「古典以後の時代」に推移した。その際に意思決定機関の構成も原理的な変質を遂 げだ

ドイッの大学では教授及び学生はともに成員とされていた。これは大学を「教師と学生 の共同体」(universitas magistrorum et scholarium) と見る中世的観念を根拠とするもの である。しかし，初期を除いて学生は実際の意思形成に対して影響力をもたなかったし， 教授団の分化にともなって，正教授以外の教員も除外されていった。このよらな管理体制 は，正教授大学 (Ordinarienuniversität) といわれ，ドイッ大学の典型的な構造であった。 これに対して1945年以来, 非正教授, 中間層(Mittelbau)及び学生の参加をめぐる論議が盛 んに行われた。民主化の必要性は,大学が構造改革することなしに大規模化すると顕著にな る。正教授大学は1960年代の大学紛争を契機として, 集団管理大学 (Gruppenuniversität) へ移行した。そこでは，意思決定機関は集団代表制原理に基づいて構成される。つまり， すべての成員がその地位に応じて区分され，自己の所属する集団の代表者の選挙を通じて 意思決定に参加するのである。

集団管理大学が1973年の連邦憲法裁判所判決のなかで, 基本法第 5 条第 3 項の定める学 問の自由と両立可能とされ，さらにそれが大学大綱法に採用されたことは，意思決定機関 の構成に执いて決定的な意味をもった。確かにキリスト教民主同盟（CDU）は教授が多数 を占めることを支持し，社会民主党（SPD）は中間層・学生への配慮を重視したから，州 大学法に括ける具体的な規定は多様であったが，いずれにしても集団代表制原理に依拠す るものであったここうした状況の中で，1982年に連邦の政権が SPD から保守的な CDUを 中心とするコール (H. Kohl) 内閣に変わったことから大学政策が転換し，ヴィルムス (D. Wilms) 連邦教育学術大臣の下で大学大綱法の見直しが着手されることになった。 


\section{（2）大学大綱法第三次改正における争点}

集団管理大学の意思決定機関の構成原理である集団代表制原理は，今日の意思決定機関 の構成を考光る際に最も重要な意味をもつ。そこでは各成員集団に共同決定権が分与され る。1976年の大学大綱法では, 意思決定機関の中で各成員集団に配分される議席・議決権 はその機関の任務，大学成員の資格，職務，責任，関係度に応じて定められる。そして成 員集団として，(1)教授 (2)学生 (3)学術的及び芸術的協力者並びに大学助手 (4)その他の協力 者という4 集団が形成され，すべての成員集団が意思決定機関に議決権を有する代表を送 らなければならないと定められていた（§38 HRG）。

一方，大学大綱法改正専門家委員会の報告によれば，この改正は集団代表制原理を補完 する試みとして把握された。報告は「大学の重要な決定機関に和けるすべての成員集団の 代表の原理を肯定する」としながらも「大学の専門上の区分及びその使命を十分に考慮す るために，集団代表制原理と並んで，専門代表制原理があらわれなければならない」とい う。 具体的には専門部代表が職権により評議会の成員になるのである。従って評議会は集 団代表制原理による各成員集団の代表者と，専門代表制原理による各専門部の代表者に よって構成されることになる。しかし，ひとつの機関の構成が二つの異なる原理によって 決定されることから問題が生じる。つまり専門代表制原理に基づいて専門部代表に議決権 が与兄られるならば, 評議会全体に占める教授の比率は極めて高くなる。ヴィルムス教育 学術大臣の狙いは大学に扔ける共同決定を制限することであった。すべての学部が再び学 部長によって代表されるから，大学の執行機関である評議会では常に教授が多数を占める ことになり，その結果，正教授大学といら昔の状態が回復されるのである。それに対し社 会民主党は連邦議会において「正教授大学が，新たな任務，課題，問題提起を乗り越える 能力がないことが証明された後に，大学成員の集団を立法の範囲内で，また憲法判決の範 囲内で決定に参加させるといら集団管理大学が試みられたといらことに注意を喚起しても よいだろら」と指摘し，専門代表制原理の導入に反対した。これは，連邦政府による専門 代表制原理導入の方針は，「集団管理大学からの方向転換」であり，大学の管理体制が正教 授大学に後退すると考えられたからである。

それでは，専門代表制原理は集団代表制原理と矛盾し，意思決定機関の構成に招いて両 原理を同時に適用することは不可能なのか。

\section{2. 専門代表制原理}

\section{（1）専門代表制原理の意義}

専門代表制原理は，ドイッ大学の理念に基づく構成原理である。ワイマール共和国のプ 
ロイセン文部大臣ベッカー（C. H. Becker）による「細分化された専門分野の寄せ集めに なっている大学」の改革は学問の総合の理念に基ついたものであったじ, また1946年に 『大学の理念』を著したヤスパース（K. Jaspers）に拈いてはあらゆる科学は互いに連関 し，「大学は一つの全体としての諸科学の統一からして，知識能力を最大限に充実しょう とするもの」として把握されだ。つまり総合性が重要なのであって, このことは大学管理 体制にも反映されるのである。ティーメは「大学は諸科学の宇宙であると理解され，その 中央組織の構成要素の中で諸科学の総体が何らかの方法で描写されなければならない」と いら年，これは評議会に「諸科学の宇宙」の一部である専門部が参加することに通じる。 評議会の任務は，州法にみられる「評議会は，この法律及び学則 (Grundordnung) に特別 の定めのある場合を除いて，全学に関わる事項を遂行する」という条文に要約されよう。 このような性質は, 大学の基礎的組織単位である専門部が評議会での決定に関与すること の必然性を意味し，専門代表制原理は肯定される。

しかし問題になるのは，専門代表制原理による代表の資格である。評議会に派遣される 専門部の代表者は通例専門部長であり，専門部長は当該専門部の教授から選出される （§64V HRG）から，評議会が教授によって支配される可能性がある。そして教授以外の 集団の影響力が低下し，かつての正教授大学のような管理体制が復活するのではないかと いう懸念が生ずるのである。二つの原理は対立するものだといら見解はこのことを根拠と するが，はたして専門代表制原理と集団代表制原理とは矛盾するのか。

\section{（2）専門代表制原理と正教授大学}

「正教授大学」とは, ドイツ大学の伝統的な管理体制の呼称である。正教授は, 終身的に 任命された官吏であり，講座担当教授（Lehrstuhlinhaber）として学部教授会の成員であ り, また学長, 学部長及び各学部教授会によって選出される評議員の被選挙権を有する。 正教授大学の評議会は, 一部の例外を除いて学長, 副学長, 学部長, 各学部教授会によっ て選出される評議員によって構成されるが，これらは同時に正教授でもあった。このこと は正教授大学が少なくとも専門代表制原理にかならことを示す。むしろ批判が向けられた のは, 評議会, 学部教授会等の意思決定機関が正教授の強力な影響下に和かれ, 助手や学 生はもちろん員外教授, 講師, 私講師さえ, 事実上の共同決定権をもつものではないとい ら状態であった。そのような管理体制の中では，正教授以外の大学成員を含めた学問的論 争の自由が失われることになるから，正教授大学は「専門上の立遅れの原因」にさえなる のである。

正教授大学崩壊の原因は，それが革新性に乏しく，元来改革に不向きな管理体制であっ 
たことだと考兄られる。これはシェルスキー（H. Schelsky）のいら「社団的大学改革」, つ まり「大学の自治に根ざした, 大学構造上無理な大学改革の試み」に相当すると考えられ る。このタイプの改革では, 大学が対外的な自治によって国家権力を拒否しているため, ヒトラー（A. Hitler）の「教条主義的」大学改革や, フンボルト（W. v. Humboldt）の 「文化国家的」大学改革に和いて作用するような, 大学の外部からの「推進力」が欠如して いることから，大概は現状からの変化を嫌う「安定化の傾向」を免れることができない。 大学紛争期の「三者同権論」に反対したゲック（W. K. Geck）さえ,「決定権をもつ委員会 に招いても，その管轄事項に応じて学生の参加権を強化することは許される」といい，限 定的ながら学生の参加を肯定する。意思決定から排除された大学成員が, 正教授による大 学支配に対して刺激を与えることは, 大学改革にとってプラスの側面もあったのである。 このことは, 正教授大学を否定し, 集団管理大学の必然性を証明するのに有効であり, た専門代表制原理導入への反対論の根拠と同一であると見ることができる。専門代表制原 理によって専門部代表が意思決定機関に所属することの長所は, 学部長が評議会の成員に なるという昔のドイッの大学構造を一貫して継続していることのみとさえいわれる。で は, 専門代表制原理は正教授大学々不可分なのか。

確かに正教授大学の崩壊に並行して専門代表制原理の実現が困難になったことは事実で ある。「継続的に増加する多数の学問分野によって, 諸科学を総合的に描出することは, 多 かれ少なかれ虚構になった」といわれる。かつて評議会には通例学部長が所属していた が，学部が多くの専門部に細分化されたことにより，すべての専門部が実際に影響力をも つことは可能ではなくなった。この点で専門代表制原理と正教授大学とが軌を一にしたの であった。しかし，このことを理由に両者を同義と見なすことはできない。専門代表制原 理は, 大学の専門上の組織編成を顧慮した構成原理であることが第一義なのであって, 教 授集団の権限の強化は，それに付随して生じるにすぎず，専門代表制原理の本質ではない。 それゆえ元来両者は峻別されるべきものである。大学大綱法の第三次改正による専門代表 制原理の導入に拈けるこの原理の把握のしかたには問題があったといえよう。

\section{3. 集団代表制原理}

\section{（1）集団代表制原理の根拠}

専門代表制原理が，組織間の調整を意図した構成原理であるのに対し，集団代表制原理 は成員集団間の利害の調整を意図する構成原理である。大学のすべての成員が意思決定に 関わる根拠は, 大学が「公法上の社団」であること, 教授だけではなく助手層及び学生も 「学問の自由」を享受する主体であることにある。 
「公法上の社団」は行政法上の概念である。それは，遂行されるべき任務を履行する際 に, 何等かの協働権が認められる成員 (Mitglieder) から構成される。大学大綱法に拈いて も大学は「公法上の社団」であり，その成員は「当該大学に本務として勤務し，公務に従 事する者及び学籍登録をした学生とする」（§36 I HRG）と定められている。リュトイェ （J. Lüthje）によれば, 成員関係は, 社団の自治における協働の権利及び義務, 並びに大学 の施設，建物及び資金の利用の権利を内容とする。そしてここでいら利用権は営造物の 「利用関係」によるものではなく，「社団の成員資格（Mitgliedschaft）」の一部だとされ る。このことは大学成員が, 大学の単なる「利用者」ではないことを意味する。従って 「公法上の社団」である大学に括いては，教授だけではなくその他の成員も意思決定に参 加することが可能なのである。一方，「学問の自由」は基本法によって保障される基本権で あるが, 大学教員の「研究の自由」及び「教授の自由（Lehrfreiheit）」だけではなく, 助手 層及び学生の「学習の自由」もそれに含まれることも，教授以外の成員が意思決定に関与 することの妥当性を示す。

しかし，ここに揭げた集団管理大学の根拠に対して疑問が呈されることがある。例え ば，「公法上の社団」の成員の権利の問題に関しては，同じく「公法上の社団」であり民主 的に管理される地方公共団体との相違が指摘される。つまり大学には民主的な要素は本質 的に合わないし，学生は，地方公共団体の市民といらような意味での成員ではないといわ れる。これは，大学教員が国家公務員としての義務と責任をもち，また専門家でもあるの に対し，学生が大学に在学するのは限られた期間であり，しかも職業訓練といら個人的な 利益のために学習するにすぎないといら成員としての性質の違いが根拠とされる。また， 大学の学生 (Student) は下級学校の生徒 (Schüler) とは異なり, 大学での学習が学問の過 程への積極的な参加に目標を拈くとしても，「学習の自由」による学生の参加は, 主として 授業のテーマに関して質問したり，支持する学説について意見を述べる機会が与えられる ことにある。それに対して，授業の内容と進行の決定自体は，大学教員の教授の自由及び 基本法第 5 条第 3 項第 1 段によって保障された憲法上の地位の一部であると解釈される。 しかし，これらの疑問があるとしても，「学問の自由」は，他の大学成員に対する配慮なし に決定する権限を大学教員に保障するものではない。大学に所属する者の利害の調整・調 和の必要性は集団管理大学の妥当性を示すといえる。ただし各成員集団の地位の違いから くる格差の問題は依然として存在するのであり，構成原理としては曖昧さを残している。

\section{（2）集団代表制原理の本質}

集団代表制原理によれば，意思決定機関は各集団の代表者によって構成されるが，原理 
的には各集団の議決権の比率は一様ではない。ティーメは集団管理大学を二つのモデルで 把握した。一方はいずれの集団も絶対多数を占めない「真の」集団管理大学であり, 他方 は教授が絶対多数を占めるモデルである。両者は対立関係にあるのではなく，程度に差が あっても根本的には同一の理念に立つものである。このモデルは, 集団管理大学の意思決 定機関に和ける成員集団間の格差あるいは平等性には，「幅」があることを意味する。さら に敷衍して, 成員集団間の平等性を高めれば所謂「三者同権」に近づき, 逆に集団間の格 差を広げて教授に優越した地位を認めるならば，正教授大学に近い構成になる。集団管理 大学の意思決定機関の構成が多様であるならば，「集団代表制原理＝平等性のある構成」 と直ちに理解することはできない。むしろ議決権が特定の集団に偏って配分され，その他 の集団の決定に対する影響力が事実上無に等しいほど格差があるならば，集団間の調整機 能は失われている。従って, 集団代表制原理は, 限定された意味に拈いてのみ, 成員集団 間の利害の調整を意図した「民主的」な管理体制になりらるのである。

大学大綱法第三次改正において論争になった専門代表制原理の導入によって生ずる構成 原理の問題は，こうした意味で理解することができる。改正法に打沙る意思決定機関の構 成原理は，根本的には集団代表制原理である。しかし，専門代表制原理の採用により専門 部代表が加わることで正教授大学に近い状態になり, 教授以外の集団の共同決定権が実質 的になくなる可能性がある。意思決定機関がこのように構成されるならば，もはやそれ は，集団管理大学とは似て非なるものであると考える。

以上のことから，集団代表制原理と正教授大学の対立する性質が明らかになる。集団代 表制原理の本質は各集団の適度なバランスの下で決定が行われることであり，意思決定機 関の構成は「多元的」な状態にある。それに対して正教授大学では正教授のみによる「同質 的」な構成にあるといえる。各成員集団への議決権の配分が集団に属する構成員の地位・ 資格によって異なるとしても，少なくとも決定に対して実質的な影響力を失わない程度に 「多元性」が確保されるならば，それは本質的に集団代表制原理に依拠していると見るこ とができる。もちろん, 専門部間の調整に関して明確な内容をもたない集団代表制原理の みを意思決定機関の構成原理とすることは, 妥当ではない。しかし, 集団代表制原理を専 門代表制原理で「補完」することが, 成員集団間の調整のために必要な「多元性」の否定 につながるならば，それも同様に妥当とはいえない。そこで二つの原理を如何にして調和 させるかといら原理の適用が問題になる。

\section{4. 構成原理の適用における問題}

大学の意思形成に执いては専門代表制原理による組織間の協調も，集団代表制原理によ 
る成員集団間の調整も，欠くことのできない要素である。それゆえ原理の本質的な意義 が，意思決定に至る過程で十分に顧慮されるべきである。とはい光，その適用のあり方は 一様ではない。集団管理大学以前にも集団代表制原理の目指すところを実現しょうとする 仕組がなかったわけではない。所謂正教授大学の評議会に学生, 助手, 官吏等の代表者が 加わることがあった。しかし議決権をもつのはほんのわずかであり，意思決定に対し助手 や学生が直接的に関与することには消極的である。集団間の調整は意思決定機関に扔ける 各成員集団の情報提供及び意思決定機関外での協働に強く現れる。従ってこのような意思 決定過程は，専門代表制原理を《主》とし，集団代表制原理を《従》とした過程と見るこ とができる。一方，1976年の大学大綱法が採用した管理体制は，基本的には集団管理大学 であったが，管理全体を見渡すと専門代表制原理の要素も見ることができる。例えば「共 同委員会」は「複数の専門部の協力を必要とする任務」のために設置される機関であり ( 865 I HRG)，専門部間の調整機能をもつ。

以上のように補完的性質をもつ手段によって，総体的に二原理を配虑することは可能で ある。しかし調整の結果が最終的な決定で否定されないとも限らない。バウア（T． Bauer）は共同委員会における直接的な協働の意義を認めてはいるが，専門部が意思決定 機関としての評議会に和ける協働権をもつことの必要性を主張している。そ吕) それは, 当該専 門部が関係する教授と学習のすべての問題について, 評議会での協働権をもつことによっ てのみ, 基本法第 5 条第 3 項から推論される「学問に相応しい決定構造」への前提が保持 されるからである。しかし評議会の議決権レベルでの二つの原理の適用は，補完的な機関 に比べて容易ではない。議決権配分ではバランスが重要な意味をもつが, 次元の異なる二 つの原理から，各専門部あるいは各成員集団に配分する議決権の比率を導くことは原理的 に不可能と考元られる。大学大綱法第三次改正の問題点はこの点にあった。

当初この改正では評議会の議決権レベルで尃門代表制原理の採用が図られた。しかし， 実際に第三次改正法に定められた構成は，必ずしもそらなっていない。専門代表制原理 は，評議会に「専門部代表が職権により議決権もしくは審議権をもって所属する。これと ならんで州法は複数の専門部に対し一人の専門部長もしくは共同委員会の長が所属するこ とを予定することができる」（\$38II HRG）といら形で現れている。従って例えば八イデ ルベルク大学ではすべての専門部代表が議決権をもち, 専門代表制原理を強調したため に, 評議会の成員 40 人中 30 人は教授であり, その他の集団の比率は低下している。逆に専 門部代表に審議権のみが与兄られる場合には，議決権配分は集団代表制原理に基づき， ゲッティンゲン大学では評議会の成員 13 人中教授は 7 人である。それゆ先議決権レベル では，必ずしも専門代表制原理は適用されていないのである。 
このように大学大綱法第三次改正法は, 最終的な決定に参加する議決権を配分するため の原則を一律には定めていない。結局，この改正に扔いては，意思決定機関の構成の決定 的なモデルを提示することはできなかったのである。

結

今日, ドイツの大学の意思決定機関は，集団代表制原理及び専門代表制原理を基礎にし て構成されている。両原理は本質的には矛盾するものではないが，適用の際に葛藤する局 面があった。しかし，このことは両原理が意思決定機関の構成原理として無用であること もまた二者択一が許されることも意味しない。意思決定機関がいずれの原理を重視して 構成されるとしても, 意思決定において, 成員集団間及び専門組織間の調整が必要である ことには変わりはない。そして, 適用上の困難があるかぎり, 両原理の有効な調和が試み られることが必要である。そのためには，委員会等の下位機関を含めた意思決定過程の総 体に括いて十分な審議を行らことによって, 意思決定機関の調整能力を補完することが肝 要であろら。

\section{〔注]}

(1) ここでいら国家とは，実際には州である。今なお多くの大学は州立大学である。 1969年の基本法改正により，連邦に大学制度の一般原則に関する大綱的立法権が与え られたが，それは具体的には大学大綱法及び大学建設計画に関する権限である。ぬた 連邦防衛大学や私立大学も存在するが, その数は少ない。

(2) 高木英明「ドイツ大学の法制的本質一『大学の自由』との関係において一」(『京都 大学教育学部紀要VIII 1962)。Werner Thieme, Deutsches Hochschulrecht, 1986, S.106-111; Jürgen Lüthje, §58. "Rechtsstellung der Hochschule”, Erhard Denninger, Hochschulrahmengesetz-Kommentar-, 1984; Peter Dallinger, §58. "Rechtsstellung der Hochschule", P. Dallinger/C. Bode/F. Dellian, Hochschulrahmengesetz-Kommentar-, 1978.

(3) 大学大綱法については, 文部省大臣官房調査統計課『西ドイツにお污る大学大綱 法』1978, 改正法については, 児玉嘉之「西ドイツの大学政策一『大学大綱法』の改 正をめぐってー」(『レファレンス』昭和61年 5 月号, 国立国会図書館), 長島啓記「西 ドイツの改正大学大綱法について」(『大学資料』第102号, (財)文教協会, 1988), 文部

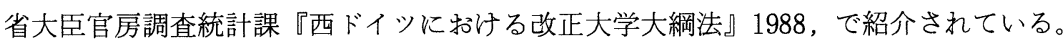

(4) W. Thieme, 1986, S.226. ティーメは, 専門代表制原理の問題点として評議会の規模 の拡大による非能率性を挙げているが，それは複数の専門部から一人の専門部代表が 評議会に所属することによって解消されるという（S.249）。な持専門部は大学の基礎 的組織単位である（\$64 I HRG）と規定される。歴史的には学部 (Fakultät) の後身 であり, 州によっては今日でも学部という名称を採用している（W. Thieme, 1986, 
S.251-274)。

(5) Peter Moraw, Kleine Geschichte der Universität Gießen, 2. Auflage, 1990, S.2-3.

(6) Thomas Ellwein, Die deutsche Universität, 1985, S.242-252 ; Rainer A. Müller, Geschichte der Universität, 1990, S.105-107.

(7) 第三次改正法により, (3)の集団は「上級助手, 上級技師, 学術助手·芸術助手, 学術協 力者・芸術協力者」に改められた（Bundesgesetzblatt, Nr.56, 1985, S.2092-2093.)。

(8) Deutsche Universitätszeitung (DUZ), Nr.3/1984, S.14-15.

(9) Der Spiegel Nr.44/1984 (29. Oktober), S.62-63.

(10) Verhandlungen des Deutschen Bundestages, S.9078 (10. Wahlperiode, 123. Sitzung, 28.2.1985).

(11) ハンス＝ヴェルナー・プラール（山本尤訳）『大学制度の社会史』法政大学出版局, 280-281頁 (Hans-Werner Prahl, Sozialgeschichte des Hochschulwesens, 1978)。 ルムート・シェルスキー（田中昭徳・阿部謹也・中川勇治訳）『大学の孤独と自由』未 来社, 1970, 223-227頁。Helmut Schelsky, Einsamkeit und Freiheit, 2., um einen 》Nachtrag 1970《 erweiterte Auflage, 1971, S173-176.

(12) Karl Jaspers, Die Idee der Universität, 1946, S.73-75. (森昭訳『大学の理念』理想 社, 1955, 150-152頁)。

(13) W. Thieme, 1986, S.225.

(14) § 71 I Landesgesetz über die wissenschaftlichen Hochschulen in RheinlandPfalz.

(15) W. Thieme, Deutsches Hochschulrecht, 1956, S.172-175, S.257-260.

(16) ハンス=ヴェルナー・プラール 前掲書310-311頁。マックス・プランク教育研究 所研究者グループ（天野正治監訳）『西ドイツの教育のすべて』東信堂，1989，260頁。

(17) H. Schelsky, 1971, S.122-124

(18) Wilhelm Karl Geck, in : H-H. Rupp, W. K. Geck : Die Stellung der Studenten in der Universität, 1968, S.66.

(19) W. Thieme, 1986, S.225-226.

(20) Eike Mußmann, "Die öffentliche Verwaltung als Teil der öffentlichen Gewalt", Rudolf Schweickhart, Allgemeines Verwaltungsrecht, 1979, S.40; W. Thieme, 1986, S.107-108.

(21) Jürgen Lüthje, in ; E. Denninger, 1984, S.773-774.

(22) W.Thieme, 1986, S.121-123.また「往々にして成員といらことが高く評価されすぎ ているのに対し, 適格性, 任務及び責任の違いは軽く扱われすぎている」といわれる (W. K. Geck, 1968, S.38-39)。

(23) G. Leibhorz/H. J. Rinck/D. Hesselberger, Grundgesetz-Kommentar an Hand der Rechtsprechung des Bundesverfassungsgerichts-, 6. Auflage, 1979, S.264-265.

(24) W. Thieme, 1986, S.210-211.

(25) シェルスキーも同様の見解をもっていた(H. Schelsky, in : P. Mikat/H. Schelsky, 
ドイッの大学に括ける意思決定機関の構成原理 Grundzüge einer neuen Universität, 1966, S.53-59.)。

(26) Thomas Bauer, Wissenschaftsfreiheit in Lehre und Studium, 1980, S.111-113.

(27) Ruprecht-Karls-Universität Heidelberg, Band I Personal-und Informationsverzeichnis 1989; Georg=August=Universität Göttingen, Vorlesungsverzeichnis Sommersemester 1989. 